\title{
CORRECTION
}

\section{Correction to: Evaluation of forward head posture in sitting and standing positions}

\author{
B. Shaghayeghfard ${ }^{1} \cdot$ Amir Ahmadi $^{1,2} \cdot$ N. Maroufi ${ }^{1} \cdot$ J. Sarrafzadeh $^{1}$
}

Published online: 16 July 2021

○) Springer-Verlag GmbH Germany, part of Springer Nature 2021

Correction to: Eur Spine J (2016) 25:3577-3582

https://doi.org/10.1007/s00586-015-4254-x

The first author name has been incorrectly published in the original publication. The complete correct name should read as follows.

B. Shaghayeghfard

The original article has been corrected.

Publisher's Note Springer Nature remains neutral with regard to jurisdictional claims in published maps and institutional affiliations.

The original article can be found online at https://doi.org/10.1007/ s00586-015-4254-x.

Amir Ahmadi

amirahmadi.pt@gmail.com; ahmadi.a@iums.ac.ir

1 Department of Physiotherapy, School of Rehabilitation

Sciences, Iran University of Medical Sciences, Tehran, Iran

2 Iranian Center of Excellence in Physiotherapy, Tehran, Iran 